УДК $82-1 /-19$

\title{
С.А. Панарин
}

\section{ОДИНОКИЙ ГОЛОС ФЛАУТИНО ИЛИ ПРИСТРАСТНЫЕ ЗАМЕТКИ О СТИХАХ ИРИНЫ КАДОЧНИКОВОЙ}

Ирина Кадочникова - молодой ижевский поэт, автор двух поэтических сборников. Ее поэзию отличает пронзительная искренность, абсолютно преобладает в ней жанр лирического стихотворения. Стихи Ирины могут быть отнесены к философской, пейзажной, любовной лирике; но, независимо от этих делений, ее поэтическому долу довлеет мысль, почти всегда глубоко пережитая. Часто это философское размышление о пространстве, Космосе и растворении в нем, о бытии, инобытии и возможных инвариантах последнего. Центральное место в лирике Ирины занимает утверждение одиночества как единственно верного пути к самопознанию и потому блага более ценного, чем любовь, которая в немногочисленных любовных стихах фактически отождествляется с несвободой. В то же время, благодаря таким качествам поэзии Кадочниковой, как честность поэта с самим собой и отсутствие позы перед читателем, создается впечатление, что чем упорнее звучит в стихах Ирины апология одиночества, тем сильнее они обретают трагический оттенок. Что касается траектории формы от ранних стихотворений к поздним, то она прочерчивается у Кадочниковой очень четко: от некоторой стилистической изощренности - к нарастающей оригинальности и простоте поэтической речи. На всем протяжении творческого пути Кадочникова очень удачно использует метафору, подчас превращая в нее целое стихотворение. Благодаря этим качествам лирики Кадочниковой ее поэзия и обрела в восприятии автора статьи звучание музыкального инструмента флаутино (малой флейты).

Ключевые слова: Ирина Кадочникова, искренность, смерть и инобытие, пространственный контекст, благо одиночества, любовь как несвобода, поэзия слова, метафоризация.

DOI: 10.35634/2412-9534-2019-29-3-505-516

\author{
Я пишу на деревню дедушке длиннье письма, \\ И осенние звезды падают мне за ворот. \\ У меня в голове - вечнозеленые мысли. \\ Надо мной пропльввает никем не видимый город.
}

13-19 сентября 2018 г. в Ижевске на набережной заводского пруда был реализован масштабный проект - стрит-арт галерея «Ижевские смыслы». В нем участвовал Штаб современной поэзии «ПоэтUр», на десяти отведенных ему парапетах представивший граффити с лицами и стихами молодых поэтов Удмуртии [18]. Среди них была и Ирина Кадочникова - со строфой из стихотворения «Все куда-то едут...», вынесенной в эпиграф предлагаемого здесь текста.

Свои стихи Ирина размещает на страничке ВКонтакте ${ }^{1}$, есть у нее и печатные публикации: отдельные стихотворения, подборки ${ }^{2}$ и два сборника. Когда вышел первый из них [8], Ирина прислала мне pdf-версию, хотя я никоим образом не причастен литературному миру и мое мнение в нем ничего не значит. Причина, по которой она так поступила, представляется следующей. В 2006 г., студенткойвторокурсницей, она участвовала в проводившейся мной в г. Пушкине Всероссийской Школе молодого автора ${ }^{3}$. В ней студентов, аспирантов и молодых преподавателей учили отнюдь не поэтическому творчеству: предметом занятий были приемы и правила написания научной статьи. Однако Школа принесла Ирине практическую пользу: по окончании Удмуртского государственного университета она поступила в аспирантуру и получила степень кандидата филологических наук. С тех пор она совмещает преподавание с написанием статей о творчестве региональных поэтов ${ }^{4}$. Видимо, в благодарность за преподанные ей уроки академического письма, пригодившиеся на пути к защите, я и получил от нее печатный текст. Только оказался он не литературоведческой статьей, а сборником стихотворений. Пробежав его, я приятно удивился: «Смотри-ка, одна из твоих бывших “школьниц”, кажет-

\footnotetext{
${ }^{1}$ Следует иметь в виду, что в Стихах.ру у нее есть тезка, разместившая на этом портале 25 вполне графоманских стихотворений.

${ }^{2}$ В частности, подборка ее стихов была напечатана в «Литературной газете» [9].

${ }^{3}$ Подробную информацию о Школе см.: [13].

${ }^{4}$ См., например: $[10 ; 12]$.
} 
ся, стала настоящим поэтом!». Впечатление от следующего сборника [7] заставило меня безоговорочно отменить «кажется». Более того, я попросил Ирину сделать нечто вроде третьего сборника отправить мне те написанные после второй книги из размещенных на ее страничке стихов, которые она считает лучшими. После неоднократного чтения этих трех собраний мне и захотелось написать то, чего никогда не писал: отклик на поэтические тексты.

\title{
I
}

Начну с трех предварительных замечаний. Первое: скомпонованный из трех блоков корпус поэтических сочинений насчитывает примерно 200 стихотворений, написанных с 2008 по август 2018 г. Второе: подавляющее большинство стихотворений Ирины не имеют названий и в содержании приводятся по первой строке. Поэтому, цитируя их, я буду римскими цифрами обозначать печатные сборники (в порядке выхода), арабскими - номера страниц в них. Тогда как для стихов, еще не вышедших за пределы Сети, где они размещены на публичной страничке Ирины ВКонтакте под рубрикой «Полёт нормальный», будет использоваться сокращение [Полёт]. Третье: мои заметки вряд ли отвечают требованиям, предъявляемым к академическому литературоведческому анализу, и вот почему.

В стихах Ирины немало шероховатостей. Например, слишком уж «приблизительные» рифмы: песни его - язык волн [II, 15]; истлевают - небывалый [II, 28]; зеркалах - всяк [II, 59]. Однако этот недостаток зачастую проистекает из стремления не поддаться соблазну увести ради рифмы поэтическую речь не туда, куда ей следует двигаться по логике сказанного ранее. Или - слишком резкие переходы от образа к не связанному с ним переживанию [II. 31]: В синем море плавает дивная рыбакит, / На огромной спине носит земной шар. / Тут такое дело: внутри у меня болит / Где-то около сердиа. Там, говорят, душа. Правда, и здесь можно найти извиняющее объяснение - предположить в подобных перебивках смысла сложную ассоциативную связь, мною просто не уловленную. Но если даже признать эти спорные места бесспорными недостатками, я все равно буду далее писать о стихах Ирины почти всё время в положительном ключе. Почему?

Потому что не могу отстраниться от их восприятия, своей остротой неожиданного для меня, от произведенного ими впечатления, о котором не скажешь лучше, чем сказано другим поэтом [20]:

\author{
Человеку же казалось, \\ Будто пьяный фавн украдкой \\ Водит медленно по сердцу \\ Теплой бархатной перчаткой.
}

Правда, лирическая перчатка Ирины часто бывает холодной, а то и ледяной; но то холод пронзительной искренности. Мало того, что им не разрушается создаваемое ее «теплыми» стихами единство эстетического наслаждения и личностного сопереживания. Им создается гораздо большее - то, что в XIX в. было названо броском поэта «с седьмого этажа вниз головой с непоколебимой верой, что он воспарит по воздуху». В наши дни было найдено не менее яркое определение: «дерзость сердечной безоглядности», «короткое замыкание» - «“бесцензурное” (беззащитное!) изъявление душевного импульса, прямиком замыкающееся в сердце читателя / слушателя» [19. С. 8, 9-10].

В случае с поэзией Кадочниковой этому короткому замыканию способствует, как это ни парадоксально, ее малая известность за пределами Удмуртии. Чем менее известен поэт, тем слабее зависимость впервые с ним встретившегося читателя от ранее высказанных мнений об этом поэте и тем вероятнее индивидуальное открытие читателем неизвестной поэтической личности может стать для него действием, подобным творчеству его, читателя. Бывший археолог, я хорошо помню то счастливое ощущение собственного творения, которое охватывало всякий раз, когда удавалось в сплошном завале нащупать и расчистить древнюю сырцовую стену, почти ничем от завала не отличавшуюся. То же и с поэзией: возникает пристрастное личное отношение к своей находке - к открытому тобой поэту. Как в сходной ситуации сказал человек, захотевший представить соотечественникам неизвестных им зарубежных поэтов, «под его выбором подписалось собственное сердце» [30. S. 371].

Все же я попытаюсь отстраниться от «сердца», чтобы определить некоторые источники производимого поэзией Ирины впечатления, в меру моей ущербной компетенции разобрав то, чем это впечатление в основном создается. Соответственно, далее речь пойдет об излюбленных жанрах и темах автора, о выношенных им мыслях и отчасти о контексте их возникновения, а также об эффектах восприятия, обеспечиваемых поэтическими формами передачи этих мыслей. Как представляется, именно 
посредством этих составляющих поэтический дар Ирины обретает столь впечатливший меня élan в близком бергсонианскому понимании этого многозначного слова как творения жизни сознанием и сознания жизнью 5 .

\section{II}

Разбираемое собрание не балует разнообразием жанров: их три.

Написанное в 2010-2013 гг. трехстраничное «Странствие» - единичная проба сил в жанре апокалиптики. Увы, увы... Да простится мне покушение на каламбур, но в этом покушении на поэму экзер$c u c=$ усилие автора обрести новый поэтический опыт убил предполагавшийся экзорцизм = прорыв души читателя в трансцендентное вслед за душой некоего субъекта пророческого откровения [I, 25].

Еще девять стихотворений можно причислить к жанру посланий, хотя большинство, как видно уже по посвящениям, - с большой натяжкой: Маме [I, 21], Моим родителям [I, 61], Памяти Алексея Сомова [I, 66], Читая И.Б. [I, 28], Читая стихи С. Матвеева [I, 70]; Читая стихи Сергея Ивкина [II, 70], Читая стихи Алль Кузнещовой [II, 78]. Четкими признаками жанра обладают лишь послания В. Шихову, 2009 [I, 6] и Александру Вавилову, 2016 [II, 46-47]. Оба они доказывают, что Ирина умеет глубоко войти в чужой поэтический мир; но написаны словно бы разными людьми.

В 2009 г. то был мир ижевского поэта Владислава Шихова, который явно произвел тогда на Ирину большое впечатление богатством своего культурного багажа и изощренностью письма. Беда в том, что с помощью первого он возносит свои переживания на лирические котурны столь высокие, что перестаешь верить в подлинность возглашаемых с них переживаний. Изощренность же Шихова сугубо инволюционная: читателю предлагаются лишь предельные подобия образцам, заданным то ли элегиями Максимиана, то ли «Трофеями» Эредиа, то ли стихами Мандельштама, посвященными Ольге Арбениной. Когда проникаешь за эту оболочку, ее смысловое наполнение, почти всегда подчиненное погоне за рифмой, в лучшем случае не вызывает отклика, в худшем - создает комический эффект: А впрочем, послушай, а впрочем, послушай - в кониертном / Торжественном зале акустику тронешь фальиетом / И вырвешься в бешенстве бычьем и по акведукам / И мраморным стогнам дашь волю отравленным звукам [25. С. 143]. И по части обессмысленных красот Ирина в своем послании к Шихову вполне уподобилась его подобиям: В каком краю, изнеможен тоской, / Но исцелен давидовой строкой, / Расивел - причудливй морских камей - / Слезоточивый мир твоих камней? $[\mathrm{I}, 6]$. Скажу больше: сделать такое вот нагромождение красивостей при первом прочтении препятствующим своей округлой гармоничностью отторжению и тем самым создающим эффект правдоподобия, ей удалось, пожалуй, лучше, чем ее адресату. И впрямь слышишь звуки давидова киннора, осушающие слезы камееподобных камней-саулов...

Прошло семь лет. В 2016 г., в послании к яркому представителю уральской поэтической школы Александру Вавилову мы видим совсем другую Ирину Кадочникову. Она и теперь умело использует аранжировку поэтического мира ее адресата - «поезда» и «лифты», «больничные фильтры» и «палаты» - и не обходится без отсылки к «звукоряду», знаковому для Вавилова (см.: [21]). Но при этом она уже не смиренно восхищенный поклонник, воспроизводящий вместе со стилем и скрытые абсурды пленившего ее творчества. Теперь она - равный и независимый собеседник, чья речь созвучна стихам Вавилова подлинной, не измышленной напряженностью мировидения: Оттого и гудят коридоры на сто голосов, / Поезда, и палаты, и лифты, и весь Урал / Он-то знает, что гороскоп твой давно готов / Он ведь сам его так старательно выверял [II, 47]. Отмечу другой примечательный штрих, разделяющий три сборника. На первый приходится семь из десяти стихотворений, условно причисленных мною к жанру посланий, на второй - два, на третий - ни одного. Ирина замыкается на единственном жанре - на классическом лирическом стихотворении, написанном ямбом, иногда - верлибром, но в обоих вариантах, если воспользоваться ее же определением, «на элегический манер» [II, 14]. Впрочем, встречаются у нее и игровые стихи a la Кибиров, оригинальные и остроумные: Стране нужны метаморфозы: / Как водится, сменить бы власть. / Читатель ждет уж рифмы «розы»». / На что она ему сдалась? [I, 52]. Однако, если оставить в стороне нередкое и органичное использование евангельских образов, у нее совсем немного лирики, которую я назвал бы производной от культурного наследия, имея в виду вечные сюжеты мифопоэтической традиции, персонажей мировой культурной истории и признанные поэтиче-

\footnotetext{
5 «...Жизнь так же изобретательна, как сознание в его деятельности и, подобно сознанию, творит непрестанно» [28. S. 24].
} 
ские шедевры. К лучшим образцам такого рода можно отнести стихотворения: «И когда ты задумаешь сделать нечто» [I, 3], «Господи триединый, каждому дай свое» [I, 12], «Я помню чудное мгновенье» [I, 32], «Быть бы другим человеком» [II, 25], «Спиноза. Херем» [II, 51], «По Пармениду» [II, 64], «Однажды в городе - возможно, что в Ижевске» [II, 65], «На третий день - совсем безделье» [Полёт]. И опять: чем больше у Ирины опыт творчества, тем реже появляются у нее производные от наследия стихи, а когда все-таки появляются, тем труднее уловить их производность - настолько в них тот или иной «отправной пункт» из состава наследия усвоен и переработан. В этом смысле показательны два стихотворения, датируемыми серединой 2011 и концом 2017 г. В первом из них, «Зацветает лето, июнь в по-

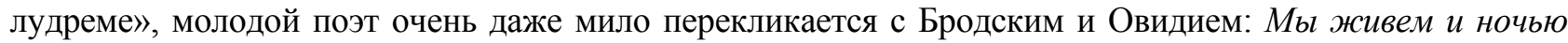
глазеем на звезды. / Tbl, конечно, не помнишь, кто такой Постум, / Да и я, говоря откровенно, не помню. / Всё смешалось здесь - и Постум, и «Письма с Понта» [I, 31]. Во втором, «Рембрандте» [Полёт] нет прямых отсылок к художнику и его картинам. По видимости, речь в нем вообще идет о другом: о зиме, вокзале, тамбуре, заляпанном тьмой... Тем не менее общей тональностью полумрака и всего двумя строками Поскольку ангель жсиут в картинах - / на линии, где свет растет из тьмы, стихотворение оправдывает свое название: создаваемое им впечатление эмоцииоальной светотени действительно вызывает в памяти эрмитажное «Святое семейство» Рембрандта.

\section{III}

Если прибегнуть к формальным градациям, то в трех сборниках много философской лирики, немало пейзажной и немного любовной. Другое дело, что границы между этими подразделениями растянуты вширь наподобие фронтиров. В особенности это относится к стихотворениям, внешне тяготеющим к пейзажной лирике. В них можно встретить непосредственное природное впечатление [II, 90]: Всего начало ноября, / Но кажется - весна в разгаре, / И снег сжимается, горя / В нежданном солнечном ударе. Но этот набросок не сменяется законченной «пленэрной» картиной, поскольку нужен как зачин для разговора с собой, завершающегося безжалостной констатацией: Мне тридиать лет, я знаю всё, / что так со мной и не случится. Здесь, как и во всей остальной лирике, не только пейзажной, поэтическому долу Ирины довлеет мысль. Мысль, куда более сложная, куда менее поддающаяся стереотипным классификациям, чем она представлена в объявлении о творческом вечере Кадочниковой в одном из книжных магазинов Ижевска: «пишет о жизни, о возможности счастья и смысла, о любви к пространству и времени, об огромности мира, о человеке ищущем и находящем» [6]. Ирина действительно пишет о «жизни» и о «возможности счастья и смысла» в ней. Но восприятие жизни, отраженное в ее стихах, определяется обычно не непосредственным впечатлением от того или иного события, от принесенного / навязанного жизнью состояния (хотя есть и такого рода стихотворения), а постоянно возобновляющимся размышлением о жизни как о бытийной возможности или невозможности в разных ее ипостасях.

Вот одна из них: весьма гипотетический, но не исключаемый переход в бытие в ином, «надземном» мире [II, 38]: Запрячь высокие звезды в рукав / И небо сверни в трубу. / Ты думаешь, хаос всегда неправ? / Спроси об этом Судьбу. / Ведь сколько никем не прожитых лет / пьлится в космической мгле. / Упрямый, дрожащчй, нетающий свет / Стелется по земле. / Ты пьешь его медленно, по глотку, / Оглядываясь иногда. / Ведь кто-то же есть над нами вверху? - / Вряд ли там пустота. Вот другая - почти буквальный словесный ремейк панели «Восхождение в эмпирей» из полиптиха «Видение загробного мира» Иеронима Босха в Галерее Академии в Венеции [II, 42]: Когда-нибудь иное измеренье / Свою всёвыносящую воронку / Откроет нам - изломанным и бренным, / И мы шагнем туда - легко и звонко, - / В другую музыку, в чакону Баха, / в непобедимый Космос быстротечный. / Я говорю и без упрека и без страха: / «Прости меня. Прощай. До вечной встречи». Вот третья: посмертное слияние с Богом, дарующее прощальную вспышку творчества [Полёт]: Ecли ты выйдешь весь, то прольешься звуком, / Станешь на миг светльм Господним слухом, / Бабочкой-невеличкой в Его руке, / Солнечныл ветерком, огоньком вдалеке. А вот - уверение себя в превосходстве мига над протяженностью, совершенно ясного момента здесь и сейчас - над непознаваемым будущим [Полёт]: Хорошо загорать в картофельных грядках / Под Господним взглядом Большого Простора. / Белогривые ходят по небу лошадки, / Поспевает смородина у забора. / Ничего мне не надо: не хочу обольщзаться / Краткосрочной милостью Интернета. / Жить - вот этим полным простым счастьем. / Бытьь - провинциальным наивным поэтом. / Говорить - легко, грести - по теченью, / Комаров кормить, зависать в зените. / Собирать в единое хитросплетенье / Дождевые и солнечные нити. 
Такое колеблющееся между вечностью и сиюминутностью восприятие жизни и так варьируемый вопрос о ее смысле неизбежным следствием имеют память о смерти. Тема смерти в стихах Ирины звучит не так настойчиво, как у лучшего поэта любимой ею уральской поэтической школы Бориса Рыжего [15], но присутствие этой темы за строкой, до рифмы - постоянно. Возможность инобытия после смерти также присутствует то зримо, то незримо и постигается по-разному - вплоть до превращения в материю не мыслящую, но каким-то образом причастную мысли. (Так причастен у Хайяма человеческий прах в составе глины, из которой сделан кувшин для вина, сознанию пьющего из этого кувшина поэта.) Когда же Ирина говорит о смерти открыто, у читателя не возникает впечатления, будто она взбирается на котурны, помянутые выше. Ее разговор о смерти серьезен, драматичен и - честен в том смысле, что не ограничивается только утешающими вариантами; он честен и «по Чехову»: вот эта моя личность - думающая и сочиняющая - исчезнет: И какие бы песни ни пел ты, когда по земле / Так беспечно идешь, забывая про вечность и Хронос, / Где-то там высоко, в невозможной космической мгле, / Мировой океан пустоты стирает твой голос [II, 16].

В стихах Ирины нет какой-то особой «любви ко времени», да и само его упоминание в них нечасто. Что касается пространства, то Ирина действительно пишет об «огромности мира»как пространства и пишет неоднократно. Обычно - в связи с представлением о нем как о Космосе в платоновском значении, т.е. о мире, наделенном благой гармонизирующей силой, мире, растворение в котором личности, казалось бы, гомологичное стиранию ее смертью, уже не вызывает душевного смятения и даже восторженно принимается: ....Может, это самое в жизни счастье - / так бесследно вписываться в пейзаж / Становиться никем - тополиным смехом, / Горизонтом, растущим сквозь этажи / И, в конечном счете, - нездешним снегом, / новогодним, невысказанным, большим [II, 96]. Но есть в ее стихах и малый, локальный «мир между Камой и Камой», ею самой определяемый как «две родины» [II, 9]. Имеются в виду райцентр Камбарка и республиканская столица Ижевск. Сейчас она живет в 600-тысячном Ижевске, но первые 17 лет жизни прожила в Камбарке и, насколько можно понять по ее стихам, до сих пор там бывает. Это самый маленький из шести городов Удмуртии: в 2015 г. в нем насчитывалось всего 10670 жителей [24]. Впрочем, как поселение Камбарка существует с 1760 г., когда здесь начал работать железоделательный завод. Соединение полугородскихполусельских размеров Камбарки и такой же ее «полу»-поселенческой структуры (на фотографиях города пятиэтажки соседствуют с индивидуальными домами и огородами), с длительным доминированием индустриальной занятости жителей и с современным ее упадком [4. С. 386; 16;22; 23] создало достаточно специфическую среду детства и отрочества, школьной жизни и внешкольных приключений будущего поэта, - среду поселковую. В ней для детей еще возможны игры во дворе, жесткое уличное товарищество, вылазки без опеки взрослых в ближайшие окрестности, как итог, - нерефлексируемое породнение с пространством, охватываемым взглядом, исхоженным ногами. Память о таких теплых, «свойских» взаимоотношениях с местом хорошо видна в тех стихах Ирины, где присутствует Камбарка. По контрасту она во многом определила и поэтическое восприятие Ижевска: это место, любимое уже осознанно, по выбору; и потому любовь к нему осложнена отчетливым осознанием его черт, отталкивающих своим антиэстетизмом [Полёт]: Город мой серый, синий. / Шатким забором привет. / Здесь красоты и в помине, / Если по-честному, нет.

Сначала поселковая, наполовину природная, среда, затем урбанистическая среда республиканской столицы, этого символа иноэтничной идентичности, наиболее явно заявляющей о себе как раз в сфере культуротворчества... Каково их значение для поэзии Кадочниковой? Прежде чем дать свой ответ, приведу простенькую наводящую цитату: «...Под контекстом понимают все то, что выходит за границы текста: историю его создания, литературную эпоху, литературную критику на этот текст, отзывы читателей, биографию автора, его мировоззрение, психологическое состояние в момент написания этого текста, интертекстуальные связи этого текста с другими текстами» [2. С. 10]. Время в этом перечне представлено в самых разных видах, место же полностью выпало. Между тем, не отрицая очевидной контекстуальной значимости времени в поэзии Ирины, я все же склонен на первое место в иерархии ее возможных контекстов поставить место. Именно «двоичное» пространство Камбарки и Ижевска и отпечатки, наложенные на личность поэта двумя в чем-то дополнявшими, а в чем-то отталкивавшими друг друга сочиализачиями по «месторазвитию», и образуют ядровый контекст ее поэзии.

Теперь - о «человеке ищущем и находящем». В стихах Ирины он ищет разное: непривычное [I, 33] и привычное [I, 39], погружение в мир [Полёт: Как в огороде нашем лебеда...] и изоляцию от него [II, 71], обновление души от встречи с лесом [II, 67-68] и деньги для выплаты ипотеки [II, 87]... Однако чаще всего он ищет и находит одиночество. 
Тема одиночества человека в мире занимает в поэзии Ирины едва ли не центральное место. Она признает одиночество благом: ставит его в один ряд с блаженством [II, 17] и даже сторожит [II, 56]. Можно, конечно, предположить, что автор, поддавшись генеральной тенденции последних поэтических лет, возвращает в свою поэзию лирического героя «в его традиционном понимании - как образ, связывающий внутренней мир стихотворения с лицом, стоящим за произведением» [26. С. 21]. И что обусловленная теми или иными личными обстоятельствами наклонность автора к поэтизации одиночества этим возвращенным лирическим героем возводится в абсолют. Или, наоборот, признать, что и в данном случае вся авторская индивидуальность поэта заключается не более, чем в его ФИО, и поэт Ирина Кадочникова - лишь вечный переписчик Скриптор, чье бытие как Автора обусловлено текстами, а те, как известно, «сотканы из цитат, отсылающих к тысячам культурных источников» [1. С. 388-389]. В том числе - из цитат на очень популярную у людей творческих тему одиночества. Можно даже влить в прозрачную струю постмодерна толику мутного позитивизма: мол, концентрация Ириной в ее писаниях неявных цитат на тему одиночества - это своего рода знамение наступившего времени «разъединенных душ». Но мотив одиночества звучит в поэзии Ирины так сильно, - не слабее, чем у Фаулза в «Любовнице французского лейтенанта» или у Алексея Иванова в «Географе», - что совершенно не верится ни в игры воображения, ни в устранение Автора. А верится в то, что мотив этот, пусть даже восходящий в своих основах к культурным источникам и/или самым что ни на есть вульгарно социологическим образом «отражающий» так называемый запрос времени, - мотив этот звучит в исполнении Автора, а не Скриптора. И если все-таки допустить, что у Ирины он предзадан и аранжирован совместно культурным наследием и кратким временным срезом текущего десятилетия, то, что получилось, несет на себе глубокий преобразующий оттиск неповторимого личного опыта, отлившегося в настоящее credo: Bom $u$ делай всё не так, как хотят от тебя другие - жсии один / Понимай Бога на собственный лад,/ будь пронзительней песни родных осин <... Р Не горюй о ране, не плачь о дожде, / не печалься о жизни, глядя в окно. / Знай, что каждый день - твой последний день / И что все дороги тебя всё равно / Приведут к самому себе, ибо сам / Ть и есть свой странноприимный дом - / Рукотворный дворец, расхристанный храм, / Вертоград, перевернутый вверх дном [II, 50].

IV

То пятое время года,
Только его славословь.
Дьии последней свободой,
Оттого что это - любовь.
Высоко небо взлетело,
Легки очертанья вещей,
И уже не празднует тело
Годовщинь грусти своей.

Источник такой веры в одиночество - не единственный. Он и в настроениях времени. И в наведенном знании, почерпнутом у Блаженного Августина и Конфуция, Баруха Спинозы и Каллистрата Жакова (их в своих стихотворениях упомянула сама Ирина). И в специфике поэтического творчества: как бы ни был поэт общителен в жизни, сочиняя стихи, он замыкается в своем «вертограде». Но есть еще один источник: он обнаруживается в той горстке стихотворений, которые могут быть признаны образцами любовной лирики Ирины и лучшими образцами ее лирики в целом.

Я не случайно написал «в горстке»: среди двух сотен стихотворений, вошедших в три сборника, лишь с десяток можно причислить к любовной лирике. Само же слово «любовь» встречается и того реже. Причем едва ли не в половине случаев оно по воле автора оказывается в не слишком греющих душу сочетаниях типа «смириться... с беленой-любовью» [I, 8], «и всё, что есть у нас - любовь да мука» [I, 14], «и если боль твоя любовью не зовется» [II, 58]. Поэтому я и предварил этот раздел стихотворением Анны Ахматовой: оно составляет резкий контраст отражению любви в лирике Кадочниковой. Ибо в стихах последней любовью не отменяется, как в ахматовском шедевре, память о годовщинах грусти, мир поэта не наделяется заново высоким небом и предметной легкостью, сам поэт не уносится в особое состояние, превосходящее любое время года, и любовь никогда не восславляется. И, если у Ахматовой любовь уравнена с пьянящим глотком свободы, пусть даже последним, то у Кадочниковой - с несвободой без всяких оговорок. 
Здесь опять встает проблема лирического героя. С тех пор как было заявлено, что «для нас уже неприемлемо некогда бытовавшее понимание лирики как непосредственного понимания чувств данной единичной личности» [3. С. 3], во множестве лекций, пособий и рефератов лирическому герою было отказано в возможности воспроизводить любовные чувства поэта буквально. Мы, можно сказать, обязаны полагать, что переживания лирического героя в их поэтической передаче далеко отклоняются от испытанного человеком-поэтом. В стихах эти переживания могут стать нарочито приземленными либо небесно возвышенными, т. е. и очищенными от каких-то составляющих, и свободно дополненными тем, что автор не испытал, а лишь вообразил. Всё так. Но что в любовной лирике оставлено из пережитого, а что убрано - разве это не красноречивое само по себе умолчание? А те же преувеличения, выражающиеся не столько в чистом вымысле, сколько в концентрации, чрезмерной сравнительно с реально происходившим, на какой-то одной грани или фазе любви, - разве они не говорят о многом? Конечно, они говорят об особенностях мировидения поэта, его жизненной философии; но не только. Я совершенно убежден в правоте слов А.А. Потебни, восходящих, в свою очередь, к мысли Гёте о личном поводе как основе поэтического образа: «У искренних поэтов даже повидимому случайный образ имеет глубокое основание в личной жизни» $[17$. С. 47, 48]. Поэтические трансформации любовного опыта тоже говорят о его содержании, лейтмотиве и об особенностях восприятия поэтом этого опыта a posteriori.

Если так посмотреть на немногочисленные любовные стихи Ирины, памятуя при этом, что она поэт искренний, то очевидно: в амплуа лирической героини она умалчивает о зарождении любви, ее расцвете, растворении в ней, ее пьянящем переживании. Зато у нее находятся слова - все как на подбор точные и сильные, - передающие то в пережитом, что можно назвать ощущением гнета, а не разлета любовного чувства, и, как следствие, сопротивление его притяжению [II, 21]: И ради Слова, ради этой вот / Строки, которую который год / Мучительно - из глубины дрожащей / Души, как раковину достаю / Со дна морского, как любовь твою, / Открой окно, верни мне настоящий, / Трехмерныгй, бледный, грязный и большой / Великий мир, где слишком хорошо / Дышать, смотреть, совсем не вспоминая / Вот эту комнату, где мертвый свет, / Где мы вдвоем, но нас как будто нет, / Где вечное молчанье между нами.

Это стихотворение датировано 12 октября 2015 г. Спустя полгода, 7 марта 2016 г. прозвучала мантра «Живи один», и после того жизнь поэта - или лирической героини? - протекала, если судить по ее отражению в стихах, в полном соответствии с этой мантрой. Только вот именно тогда в лирике Ирины сильно обозначилось, а к концу двухлетия обрело яркое, «бесцензурное» выражение такое состояние души ${ }^{6}$, в котором трагическому самоощущению, казалось бы, уже порушившему все вехи, прежде размечавшие поэтический мир, несмотря ни на что противостоит упорно, как последний бастион, отстаиваемая вера в благо одиночества [Полет]: Это все у других, у других. / У меня - ничего, ничего: / дырка от бублика, мертвый жених / и Рождество наоборот: / пьяные ходят волхвы, / насылают всякую хворь, / говорят: «Живи ниже травы, / ни с чем не спорь: / ни с деревом, / ни с судьбой, / ни с камской черной водой, / ни с какой бедой, / ни с какой звездой; / стой себе, как стоишь, / молчи себе, как молчишь, / сохни себе, как сохнешь, / не помни себя, как не помнишь, / потому что вокруг - темный лес, / а за лесом - туман-река, / а в реке - беспробудный сон», - / вот такое мне говорят. / А я говорю: ничего, / что нет у меня ничего: / я еще похожу-посмотрю, / порадуюсь ничему.

\section{V}

Всё, что написано далее о словесной форме стихов Кадочниковой, своей фрагментарностью особенно подходит под расплывчатое - ну, прямо XXL - понятие «заметки». При этом, однако, я выгорожу себе «эску» внутри большой «эльки»: сосредоточусь лишь на отдельных компонентах так называемого речевого оформления текста в исполнении Кадочниковой.

С моей, т. е. дилетантской, точки зрения, поэзия по преобладающему средству впечатления, производимого используемыми в ней формами, может быть подразделена на три рода или вида:

1) поэзия звука; ее отличают не только такие специальные приемы, как, скажем, аллитерация, но и вообще повышенная музыкальность; яркий пример - Il pleure dans mon coeur Верлена.

\footnotetext{
${ }^{6}$ Речь идет, конечно же, о состоянии души, овладевающем поэтом лишь в моменты стихотворчества. Это надо помнить, дабы не полагать жизнь Ирины беспросветной. Приведу в этой связи слова другого поэта: «Я вовсе не так несчастна, как они (читатели. - С.П.) думают!» [14].
} 
2) поэзия ритма - необязательно «чеканная», но всегда - с повышенной значимостью соразмерности слов и интервалов между ними; яркий пример - «Прозерпина» Пушкина.

3) поэзия слова - в ней форма не наделена качеством самостоятельной, независимой от смысла красоты, производит эстетическое впечатление слитно со смыслами.

Это, конечно, «идеальные типы». В действительности все виды присутствуют у большинства поэтов, различие в пропорции и доминировании. Поэзия Кадочниковой - третьего вида, но и она не исключает игры со словом, акцентирующей его выразительность и своеобразное изящество. Другое дело, что игра эта несет на себе отпечаток, если можно так выразиться, контекстуальной оригинальности поэта - того, что я обозначил бы определением «наследие поселкового детства» - и не бросается в глаза. Но при внимательном чтении стихов Ирины различаешь эти речевые приемы, образующие траекторию ее поиска «индивидуально-творческого в языке» [27. С. 226].

Прежде всего, это органичное сочетание узаконенного традицией поэтического слова и слова «беззаконного» - не поэтического и даже, что называется, сорного. Поэтическое в его классическом понимании предполагает точность в передаче желаемого поэтом смысла и стандартизированный отклик на него читателя. Достигается такой эффект богатством лексики поэта и его мастерством в соподчинении слов в их синонимически неповторимом сочетании. Благодаря этим качествам поэтического слова им задается четкое понимание картин или образов, передаваемых поэтом, равно как и той мысли, которой эти картины и образы служат и которой они обосновываются и выстраиваются. А вот за непоэтическим словом во всех его разновидностях - диалектизмах, вульгаризмах, просторечиях, узкопрофессиональной и обсценной лексике, грубых нарушениях привычных поэтических сочетаемостей - нет такой же прочной традиции, поэтому оно может вызывать резкое отторжение. Тем не менее, большинство настоящих поэтических творцов всегда экспериментировали с непоэтическим словом. В итоге многое из считавшегося ранее непоэтическим перекочевало в стан поэтического, так что здесь уже образовалась своя традиция, немало способствующая тому, что «чистая» поэзия в ее классическом выражении читается ныне невнимательно либо вообще не читается. Но дело не только в этом, «заезды» Кадочниковой в область непоэтического не вызывают отторжения еще и по другой причине. Даже такие все еще не избавленные от их низменного происхождения слова (находящиеся, по ее определению, на грани цензуры [II, 49]), как херово и блин, не раз ею употребляемые, наделены в ее стихах функциональной значимостью. Они появляются, когда необходим резкий скачок от описания к внезапному эмоциональному всплеску. Либо, напротив, тогда, когда с помощью вот таких «сорных» средств «взлетающее» чувство оказывается застрахованным от пафосного воспарения на воздусях, и в результате предстает во всей своей естественности.

Далее. Сдержанно, осторожно, но всё же Ирина позволяет себе творить собственный поэтический язык. Неологизмов в чистом виде в ее стихах я не заметил, разве что иногда она меняет привычную форму слова на такую, которая и ловчее встает в строку по размеру, и звучит более энергично, звонко, упруго. Таков любимый ею тартарарам, совсем у нее заменивший увядший тарарам. Еще она образует сдвоенное слово из слов, далеко отстоящих друг от друга по привычной области их употребления, - и новообразования нагружаются новыми смысловыми ассоциациями. Так, в паре лебеда-судьба $[\mathrm{I}, 8]$ судьба, подобно разросшемуся сорняку, становится заброшенной, неуправляемой. Авгусm-звездочет [I, 21] из календарного месяца превращается в пору звездопада и притяжения неба, август-пожар [II,74] - в месяц краснеющей листвы и сгорающего лета, а рыба-ложь [Полёт: Не знаю, что ты расскажешь...] - в ложь скользкую и неуловимую. Есть у нее и отступления от грамматической нормы. В одних случаях они явно преднамеренные: пока Божий мир не исчезнет до вечной nустыни [II, 51]; в других же Ирину, похоже, «вёл» сам стих, словно бы подсказывая, что написать вот так, пусть и не совсем по правилам, - лучше: пропльвает никем не видимый город [II, 37]. Но самое сильное оружие Ирины на поле боя с формой - это метафора. Приведу некоторые из ее «метафорных» находок, оговорившись, что, быть может, какие-то из них и заимствованы ею непроизвольно из неизвестных мне стихов других поэтов.

Мир, зачитанный до дыр [I, 35]; стихи - проводники слепье [I, 60]; звонкие заборов позвонки [I, 61]; жизнь в узелке [I, 85]; надежда, полная подачек [II, 13]; отчаянная метла [II, 14]; вечнозеленые мысли [II, 37]; внутренняя Хиросима [II, 41]; вечность в одно касанье [II, 53]; стихи на вырост [II, 61]; горюет баба Гоморра [II, 81]; Божий свет в прожилках листвы [II, 91]; рай прохладный и проточный [Полёт: Выйду я на речку спозаранку...]; кленовый Бах [Полёт: Вот как я жил...]; расшатанное горло петуха [Полёт: Спасибо, говорю тебе, спасибо...]; человек эпохи нурофена [Полёт: 
Идешь, бывает, утром на работу...]; королевство нажитых вещей [Полёт: У человека рот всегда немой...]. Впрочем, метафоричны у Ирины целые фразы и строфы. [I, 67]: Ходит по миру девочка с решетом - / Синие очи бездонные - красота! / И собирает небесную манну - а то! / Но в решете попрежнему пустота. [II, 70]: Чужие сны, похожие на облака и тени: / Время нанижет их на бельевую веревку, / Будет носить по свету, сделает из них привидения, / Осенние листья, черно-белье листовки. [Полёт]: В огороде у дяди Саши - куры, кролики, рыжсая кошка. / Он стоит, опершись на лопату, смотрит за облаками. / Дяде Саше так много лет, что вряд ли бывает больше, / Потому и в его владеньях коса не найдет на камень. / И пока он бросает в землю заговоренные споры, / Бормочет глухие песни верхнего палеолита, / Что-то вокруг происходит: из ветхих щелей забора / Проливается свет на грядки - вода из небесного сита.

Яркие метафоры и метафоризация целых строф, меняющие смыслы слияния двух лексем в одну, гибкие переходы от речи поэтической к непоэтической, усиления эмоционального тонуса стиха не очень «приличной» лексикой - всё это можно найти у многих поэтов. В чем же тогда неповторимость формы, в которую отливается лирика Ирины Кадочниковой, сила производимого ею впечатления? Они, если воспользоваться словами Михаила Эпштейна [27. С. 241], - в индивидуальной изобретательности Ирины как поэта, в ее способности выстраивать неповторимые сочетания тех контекстов и речевых примеров, куда она помещает свое поэтическое слово.

Эта способность - дар: ее можно развить, но она должна быть заложена в человеке, претендующем на звание настоящего Поэта. Ирина Кадочникова владеет им - и его совершенствует.

\section{VI}

В заключение осталось объяснить, что в названии текста означает слово «флаутино». Оно имеет прямое отношение к тому, какое звуковое восприятие создают стихи Ирины. Конечно, такое восприятие субъективно: мне кажется, что в слуховой памяти они вызывают звучание солирующего инструмента в Largo из концерта до-мажор № 443 Антонио Вивальди. Композитор назвал этот инструмент флаутино, что сейчас во всех словарях переводится как маленькая флейта или флейтапикколо, по-итальянски - оттавино [29] $]^{7}$. Его звучание, если прислушаться, даже не до конца свободно от едва различимого всхлипа, создаваемого вдыханием воздуха исполнителем. Но и своим звуковым простосердечием, и этим захлебом воздуха в легкие артиста пение флаутино так откровенно, так интимно, так пронзительно изливает радость проживания жизни и печаль ее изживания, что трогает сильнее оркестрового многоголосия.

Равным образом скромна у стихов Ирины цветовая гамма: зеленый - синий - серый - черный много белого. Однако и этого звукового / цветового самоограничения Кадочниковой как будто мало. Она еще и никогда не кокетничает со значимыми для нее мыслями, не стремится покрасоваться их глубиной или оригинальностью, произнося их в первую очередь для себя - как нечто многократно передуманное. Более того, насколько о поведении поэта можно судить по его поэзии, Ирина всерьез воспринимает эти мысли как свои жизненные ориентиры. Написав стихотворение о поиске в собственном сердце, она с тех пор все больше с собой и разговаривает, словно вовсе забывая читателя. Но чем более она замыкает свою поэтическую речь на себе, тем сильнее располагает к вчитыванию в ее стихи, к улавливанию их смыслов, к сопереживанию ее переживаниям. Аналогичный парадокс следует и за наметившимися в последнее время изменениями в формах подачи мысли: за сужением, упрощением, опрощением лексики. Оставленные слова, пусть обыденные и даже «дурно пахнущие», избавившись от пышных литературных соседей, обретают убедительную, проникающую, жестокую силу элементарного, первичного смысла - и именно поэтому, вопреки устремленности Ирины к одиночеству, возвращают ее речи качество исповедальной интерсубъектности.

И поэтому же одинокому голосу Флаутино всё чаще аккомпанирует, негромко, но внятно, благодарный читательский отклик.

\footnotetext{
${ }^{7}$ Музыковеды его определяют как блокфлейту (recorder) сопрано либо сопранино [31]. В той версии, что слушаю я, камерный оркестр Dall'Arco, похоже, предпочел самую высокую по тональности блокфлейту сопранино. Однако, какой бы из возможных инструментов ни использовался, в названиях концертов он всегда фигурирует под именем флаутино.
} 


\section{СПИСОК ЛИТЕРАТУРЫ}

1. Барт Р. Смерть автора // Р. Барт. Семиотика. Поэтика. М.: Прогресс; Универс, 1994. С. 384-391.

2. Бурцева Е.А., Хасаншина А.И., Валиева Э.Д. Контекст стихотворения А. Ахматовой «Лотова жена» // Филология и лингвистика в современном мире: материалы Междунар. науч. конф. (г. Москва, июнь 2017 г.). [Гл. ред. И.Г. Ахметов]. М.: Буки-Веди, 2017. С. 10-11.

3. Гинзбург Л. О лирике. Изд. 2-е, доп. Л.: Советский писатель, 1974. 359 с.

4. Городок смерти Камбарка // ЖЖ, 09.06.2012. URL: https://www.liveinternet.ru/users/ 4214061/post223449587 (дата обращения: 29.07.2018).

5. Ирина Кадочникова. Полет нормальный // Vk.com. URL: https://k.com/public109050967 (дата обращения: 12.08.2018)

6. Ирина Кадочникова // Books and more/ 24.03.2018. URL: https://vk.com/event163697585 (дата обращения: 30.07.2018).

7. Кадочникова И. Без темы. Стихи. Ижевск: Алкид, 2017. 104 с. URL: http://sludm.com/gallery/kniga bez temy.pdf.

8. Кадочникова И. Единственный полюс. Ижевск: Шелест, 2015. 88 с. URL: https://ru.calameo.com/books/ 004082155472650965114

9. Кадочникова И.С. Зеленой памяти речного тростника // Литературная газета. 23.11.2016. № 45 (6576).

10. Кадочникова И.С. «Музыка сфер» и «крушение гуманизма» в лирике Алексея Сомова // ВосточноЕвропейский научный вестник. 2016. № 1. С. 53-59.

11. Кадочникова И.С. Реанимация // Москва. [2017]. Приложения. Конкурс 60+ URL: http://moskvam.ru/ applications/konkurs/konkurs-60-plyus/poeziya/poeziya 834.html (дата обращения: 29.07.2018).

12. Кадочникова И.С. Удмуртские лексемы в танкетках Александра Корамыслова // Вестник Удмуртского университета. Серия история и филология. 2018. Т. 28, вып. 6. С. 890-900.

13. Как писать научный текст: опыт Школы молодого автора. Учебно-методическое пособие / под общ. ред. С.А. Панарина. 2-е изд., доп. Иркутск: Изд-во ИГУ, 2014. 259 с.

14. Кузнецова И. Поэт и лирический герой: дуэль на карандашах // Октябрь. 20045. №3. URL: http://magazines.russ.ru/ october/2004/3/kuz9.html (дата обращения: 29.07.2018).

15. Непомнящих Н.А. Мотив воли к смерти в творчестве Бориса Рыжего // Сибирский филологический журнал. 2017. № 2. С. 110-120.

16. Перевощиков А.П. Камбарка // Удмуртская Республика. Энциклопедия. Ижевск: Удмуртия, 2000. С. 386.

17. Потебня А.А. Из записок по теории словесности. Издание М.В. Потебни. Харьков: Паровая литография и Литография Зильберберга и С-вья, 1905. 649 с.

18. Резидентом может стать каждый // PolyBoly, [20.09.2018]. URL: https://polyboly.com/m/Bn9LEvRnhfb (дата обращения: 15.10.2018).

19. Роднянская И. Мысли о поэзии в нулевые годы. М.: Русский Гулливер / Центр современной литературы, 2010. $134 \mathrm{c}$.

20. Саша Чёрный. Пластика // Поэзия.ру. URL: http://poesias.ru/rus-stihi/stihi-chernyj/stihi-chernyj10202.shtml (дата обращения: 08.08.2018).

21. Снигирева Т.А. «Уральский звукоряд» поэзии Александра Вавилова // Известия УрФУ. Серия 2. Гуманитарные науки. 2016. Т. 18. № 1 (148). С. 85-94.

22. Соломатин А. Город Камбарка. Юго-восточная окраина Удмуртии (фоторепортаж). ЖЖ, 24.07.2016. URL: https://solomatin.livejournal.com/570969.html (дата обращения: 29.07.2018)

23. Сперанский А.В. Камбарка // Уральская историческая энциклопедия. URL: https://slovar.wikireading.ru/66552 (дата обращения: 29.07.2018).

24. Численность населения Российской Федерации по муниципальным образованиям на 1 января 2015 года. М.: Росстат, 2015. Табл. 29. URL: http:/www.gks.ru/opendata/dataset/7708234640-ca-08-002 (дата обращения: 29.07.2018).

25. Шихов В. Четвертая книга. Ижевск: Алкид, 2017. 327 с.

26. Штраус А.В. Лирический герой в поэзии Д. Воденникова // Вестник Томского гос. ун-та. Сер. Литература. Литературоведение. Устное народное творчество. 2007. Вып. 303. С. 21-24.

27. Эпштейн М.Н. От знания - к творчеству. Как гуманитарные науки могут изменять мир. М.; СПб: Центр гуманитарных инициатив, 2016. 480 с.

28. Bergson, H. L’évolution créatrice. Une édition électronique réalisée à partir du livre L'évolution créatrice. Originalement publié en 1907. Paris: Les Presses universitaires de France, 1959. URL: http://classiques.uqac.ca/ classiques/bergson_henri/evolution_creatrice/evolution_creatrice.pdf. (accesed: 16.10.2018).

29. Flautino // Treccani. Vocabulario online. URL: http://www.treccani.it/vocabolario/flautino (accessed: 19.10.2018).

30. Klafkowski P. A Personal look at the three Swedish poets: Carl Michael Bellman, Esaias Tegner, Eric Johan Stagnelius // Studia Rossica Gedanensia. Annual 4, 2017, s. 368-387.

31. Lasocky D. The Programme // Pamela Thorby Baroque Recorder Concertos. URL: http://www.linnrecords.com/ recording-baroque-recorder-concertos-sacd.aspx (access date: 19.10.2018). 
Панарин Сергей Алексеевич, кандидат исторических наук, заведующий центром

ФГБУН «Институт востоковедения РАН»

107031, Россия, г. Москва, ул. Рождественка, 12, стр. 1

E-mail: sergpanar@mail.ru

\section{S.A. Panarin \\ A LONE VOICE OF FLAUTINO OR BIASSED NOTES ON THE POETRY OF IRINA KADOCHNIKOVA}

DOI: $10.35634 / 2412-9534-2019-29-3-505-516$

Irina Kadochnikova is a young poet from the city of Izhevsk. To date, she issued two poetic collections. What distinguishes her poetry is a complete sincerity, and what dominates it is a genre of lyric poem. Irina's poems divide into philosophical, paysage or love lyrics but all divisions irrespective, her personal poetic universe is largely overshadowed with a thought that looks - almost without exception - as inwardly brought out one. Not infrequently, it is a kind of philosophical comprehension of space and a wish for to be lost in its extension or thinking about actual being, alternative being and probable images of the latter, etc. Yet the focal point of the Irina's lyrics is solitude. She considers loneliness as the only true way to self-knowledge. Solitude appears to be for Irina more precious good than love. Indeed, love occupies a rather modest corner within her poetry; in a few love poems love is actually identified with liberty deprivation. At the same time, thanks to her honesty to herself as well as absence of any intentional self-posture in front of readers the stronger apology for solitude in her poems the more discernible become the tragic tunes of so wanted solitude. As to the means of expression characteristic for the Irina's poetry, their trajectory is clear - from moderate sophistication of her poetic language in her earlier poems towards both growing originality and generous simplicity in those pieces of poetry that appeared later. Also, throughout her creative way Kadochnikova has been very successful in using the metaphor; sometimes she transfigures the whole poem into expressive metaphor. There are just thanks to these characteristics that the Kadochnikova's poetry gained sound of minor flute flautino in its perception by the author of the article.

Keywords: Irina Kadochnikiva, sincerity, death, alternative being, local spatiality context, loneliness as a good, love as liberty deprivation, poetry of word, metaphorization.

\section{REFERENCIES}

1. Bart R. Smert' avtora [Death of the Author] // R. Bart. Semiotika. Poetika [Semiotics. Poetics]. Moscow: Progress; Univers, 1994. S. 384-391. (In Russian).

2. Burtseva E.A., Khasanshina A.I., Valieva E.D. Kontekst stikhotvoreniya A. Akhmatovoj "Lotova zhena" [Context of Akhmatova's poem "Lotto's wife"] // Filologiya i lingvistika v sovremennom mire: materialy Mezhdunar. nauch. konf. (g. Moskva, iyun' 2017 g.). [Philology and linguistics in the modern world: materials of the international conference, Moscow, June 2017. Ed. by. I.G. Akhmetov]. Moscow: Buki-Vedi, 2017. S. 10-11. (In Russian).

3. Ginzburg L. O lirike. Izd. 2-e, dop. [On the lyrics, $2^{\text {nd }}$ enlarged ed.]. Leningrad: Sovetskij pisatel', 1974.359 s. (In Russian).

4. Gorodok smerti Kambarka [Death township of Kambarka] // Livejournal.com, 09.06.2012. URL: https://www.liveinternet.ru/ users/4214061/post223449587 (access date: 29.07.2018). (In Russian).

5. Irina Kadochnikova. Polet normal'nyj [The flight is normal] // Vk. com. URL: https://vk.com/public109050967 (accessed: 12.08.2018). (In Russian).

6. Irina Kadochnikova // Books and more/ 24.03.2018. URL: https://vk.com/event163697585 (accessed: 30.07.2018). (In Russian).

7. Kadochnikova I. Bez temy. Stikhi [With no theme. Poems]. Izhevsk: Alkid, 2017. 104 s. Also available at: $\mathrm{http}: / /$ sludm.com/gallery/kniga_bez_temy.pdf. (In Russian).

8. Kadochnikova I. Edinstvennyj polyus [The single pole]. Izhevsk: Shelest, 2015. 88 s. Also available at: https://ru.calameo.com/books/004082155472650965114. (In Russian).

9. Kadochnikova I.S. Zelenoi pamiyti rechnogo trostnika [To green memory of river reed] // Literaturnaya gazeta. 23.11.2016. № 45 (6576). (In Russian).

10. Kadochnikova I.S. "Muzyka sfer" i "krusheniye gumanizma" v lirike Alekseya Somova ["Music of the spheres" and "the collapse of humanism" in the Alexei Somov's lyrics] // Vostochno-Evropeiskij nauchnyj vestnik [Eastern European Scientific Bulletin]. 2016. No. 1. P. 53-59. (In Russian).

11. Kadochnikova I.S. Reanimatsiya [Reanimation] // Moskva [Moscow]. [2017]. Prilozheniia. Konkurs 60 [Apps. Competition 60] URL: http://moskvam.ru/applications/konkurs/konkurs-60-plyus/poeziya/poeziya_834.html (accessed: 29.07.2018). (In Russian). 
12. Kadochnikova I.S. Udmurtskiye leksemy v tanketkakh Aleksandra Koramyslova [Udmurt lexems in tanketkes by Alexander Koramyslov] // Vestnik Udmurtskogo universiteta. Ser. Filologiya I Istoriya [Udmurt State University Journal. Ser. Philology and History]. 2018, №6. S. 890-900.

13. Kak pisat' nauchnyj tekst: opyt Shkoly molodogo avtora. Uchebno-metodicheskoye posobiye. 2-ye isd., dop. [Writing an academic text: the experience of the Younger Author's School. Teaching-cum-methodic manual, $2^{\text {nd }}$ enlarged ed.] / Ed. by S.A. Panarin. Irkutsk: Irkutsk State University Publishers, 2014. 259 s. (In Russian).

14. Kuznetsova I. Poet I liricheskij geroj: duel' na karandashakh [Poet and lyrical hero: pencil duel] // October. 2004. №3. URL: http://magazines.russ.ru/october/2004/3/kuz9.html (accessed: 29.07.2018). (In Russian).

15. Nepomniyashchikh N.A. Motiv voli k smerti v tvorchestve Borisa Ryzhego [Will to die: the mortal theme in Boris Ryzhyj's poetry] // Sibirskij filologicheskii zhurnal [Siberian journal of filology]. 2017. №. 2. S. 110-120. (In Russian).

16. Perevoshchikov A.P. Kambarka [Kambarka] // Udmurtskaia Respublika. Entsiklopediia [Udmurtia. Encyclopedia]. Izhevsk: Udmurtiia, 2000. S. 386. (In Russian).

17. Potebnya A.A. Iz zapisok po teoriyi slovesnosti (From the notes on the theory of literature). Izdaniye M.V. Potebni [Published by M.V. Potebnia]. Khar'kov: Parovaia litografiia i Litografiia Zil'berberga i S-v'ia, 1905. 649 s. (In Russian).

18. Rezidentom mozhet stat' kazhdyj [Anyone can become a resident]// PolyBoly, [20.09.2018]. URL: https://polyboly.com/m/Bn9LEvRnhfb (accessed: 15.10.2018). (In Russian).

19. Rodnyanskaya I. Mysli o poeziyi v nulevyye gody (Thoughts on poetry in 2000s). M.: Russkij Gulliver / Tsentr sovremennoj literatury, 2010. 134 s. (In Russian).

20. Sasha Chernyi. Plastika [Plastic] // Poesias.ru. URL: http://poesias.ru/rus-stihi/stihi-chernyj/stihichernyj10202.shtml (accessed: 08.08.2018). (In Russian).

21. Shikhov V. Chetvertaya kniga [The fourth book]. Izhevsk: Alkid, 2017. 327 s. (In Russian).

22. Shtraus A.V. Liricheskij geroj v poeziyi D. Vodennikova // (Lirical hero in the poetry of D. Vodennikov). Vestnik Tomskogo gos. un-ta. Ser. Literatura. Literaturovedenie. Ustnoye narodnoye tvorchestvo [Bulletin of the Tomsk State University. Literature, literary studies, folklore]. 2007. Issue 303. S. 21-24. (In Russian).

23. Snigireva T.A. "Ural'skij zvukoryad" poeziyi Aleksandra Vavilova [The "Ural scale" in the poetry of Alexander Vavilov] // Izvestiya UrFU. Ser. 2. Gumanitarnyye nauki [Izvestiya. Ural Federal University Journal. Ser. 2. Humanities and Arts]. 2016. №. 1 (148). S. 85-94. (In Russian).

24. Solomatin A. Gorod Kambarka. Yugo-vostochnaya okraina Udmurtiyi (fotoreportazh) [Town of Kambarka. Southeastern corner of Udmurtia. Photo report]. Livejournal.com, 24.07.2016. URL: https://solomatin.livejournal.com/ 570969.html (accessed: 29.07.2018). (In Russian).

25. Speranskij A.V. Kambarka [Kambarka] // Ural'skaya istoricheskaya entsiklopediya [The Ural historical encyclopedia]. URL: https://slovar.wikireading.ru/66552 (accessed: 29.07.2018). (In Russian).

26. Chislennost' naseleniya Rossijskoj Federatsyi po munitsipal'nym obrazovaniyam na 1 yanvarya 2015 goda [Population of the Russian Federation by municipalities as of January 1, 2015]. Moscow: Rosstat, 2015. Tabl. 29. URL: http://www.gks.ru/opendata/dataset/7708234640-ca-08-002 (accessed: 29.07.2018). (In Russian).

27. Epshtein M.N. Ot znaniya - k tvorchestvu. Kak gumanitarnyye nauki mogut izmenyat' mir [From knowledge to creativity. How humanities can change the world]. Moscow; Sankt-Peteburg: Tsentr gumanitarnykh initsiativ, 2016. 480 p. (In Russian).

28. Bergson H. L'évolution créatrice. Une édition électronique réalisée à partir du livre L'évolution créatrice. Originalement publié en 1907. Paris: Les Presses universitaires de France, 1959. URL: http://classiques.uqac.ca/ classiques/bergson_henri/evolution_creatrice/evolution_creatrice.pdf. (access date: 16.10.2018).

29. Flautino // Treccani. Vocabulario online. URL: http://www.treccani.it/vocabolario/flautino (accessed: 19.10.2018).

30. Klafkowski P. A personal look at the three Swedish poets: Carl Michael Bellman, Esaias Tegner, Eric Johan Stagnelius // Studia Rossica Gedanensia. Annual 4, 2017, s. 368-387.

31. Lasocky D. The Programme // Pamela Thorby Baroque Recorder Concertos. URL: http://www.linnrecords.com/ recording-baroque-recorder-concertos-sacd.aspx (access date: 19.10.2018).

Panarin S.A., Candidate in History, Head of the Department

Institute of Oriental Studies, RAS

Rozhdestvenka st., 12/1, Moscow, Russia, 103031

E-mail: sergpanar@mail.ru 